\title{
Prediction of Land Use Change Due to Light Rail Transit (LRT) Development in Palembang
}

\author{
I Saputra ${ }^{1}$, F A Nabila $^{1}$ \\ Received: 14 September 2019 \\ Accepted: 31 Januart 2020
}

\begin{abstract}
Light rail transit (LRT) is an effective transportation in serving the needs of movement in urban area that can increase commercial land uses. The first construction of LRT in Palembang started in 2015 which became one of the national priority projects in Indonesia. The development had an impact on land use change around the LRT corridor. This paper attempts to identify land use change due to LRT development in Palembang. This study used an explorative approach to develop an understanding of land use change due to the development of LRT and Markov-cellular automata model to predict the change. The results of this study indicated that the prediction of land use change in 2025 around the LRT corridor tends to shift more into commercial land use, this will increase investment from commercial activities in the Palembang LRT Corridor.
\end{abstract}

Keywords: Light rail transit (LRT); Land use; Change

\section{INTRODUCTION}

The transportation system acts as a tool to guide development in urban areas (Tamin, 2000). The development of the transportation system can encourage how activities can be directed to drive the progress of a city (Coyle, Bardi, and Novack, 2000). The development of an inadequate transportation system will cause traffic congestion in the city, thereby decreasing the level of accessibility. Therefore, it is necessary to develop a proper public transportation system, so that it will give a choice to the community to move using public transportation.

Light rail transit (LRT) is one of a transportation system that is effective in serving the needs of movements in the urban area. High accessibility of LRT in the urban area will generate a massive trip attraction to $\mathrm{CBD}$, which causes an expansion of commercial activities. Its expansion is growing at the LRT nodes that will lead to land use change in commercial activities (Dittmar and Ohland, 2012). The interaction of transportation systems and land use have triggered the growth of activity that will affect economic growth (Goldberg and Chinloy, 1994).

Palembang is a metropolitan area with the existence of a CBD as one of its economic drivers. The existence of this CBD must be supported by a transportation system that can connect to the surrounding area. One of the transportation systems developed in Palembang to support community movement is the rail-based transportation LRT. The first construction LRT in Palembang started in 2015 which became one of the national priority projects in Indonesia. The development of the LRT in Palembang which has 13 hubs will trigger the changes in land use. This study aims to identify and predict land use change in Palembang due to the construction of Light Rail Transit (LRT).

\footnotetext{
${ }^{1}$ Department of Urban and Regional Planning, Institut Teknologi Nasional
} 
Based on Gray and Hoel (1992). LRT is generally built in the developing part of the urban area, usually in high-density areas such as in the center of a metropolitan city. LRT is also a viable mode of transportation for areas that have large populations and are connected with crowded roads. LRT as a modern rail rapid transit can save workers because it uses modern technology and an automated system, so its services are faster, more precise and reliable (Kenworthy, 2008).

The influence of LRT on land use in developing cities is considerable because these cities tend to expand their space more quickly. Accessibility made in the LRT system can prevent the tendency of urban communities who depend on private vehicles to maintain their growth along the main and city center corridors (Wright, and Fjellstrom, 2002). Areas that are vulnerable to changes in land use are located in nodes and links, especially in cities with high economic growth. LRT as an investment in the transportation sector can increase the number of community movements and increase the pattern of activities marked in the phenomenon of land use change (Chapin and Kaiser, 1979).

\section{METHODS}

This study uses an explorative approach to develop an understanding of land use change due to the development of LRT. The analytical method used to identify land use changes is the Markov-Cellular Automata model. This model was used as the initial analysis to determine the probability of land use change that is affected by each variable (Koomen, et al. (2007). The land use analyzed is overall land use at the corridor of the LRT. Based on the result, the relationship can be seen between the tendency of land changes that will arise and what activities are predicted to change in the future. The Cellular Automata model is used to describe the direction of future land use patterns in the form of land use interventions (Waseem, et al, 2015).

\section{RESULT AND DISCUSSIONS}

Data input used as a model reference to predict land use changes. The data used were land-use data in 2010, 2013 and 2015 (Table 1), while the data used to produce the land-use transition matrix were data in 2010 and 2015. The simulation period in this study is for the next ten years until 2025, where 2015 is the primary data used before the projection.

Table 1. Land use in corridor LRT Palembang by 2010, 2013, and 2015

\begin{tabular}{|c|c|c|c|c|c|c|c|}
\hline \multirow{2}{*}{ No } & \multirow{2}{*}{ Land use } & \multicolumn{2}{|l|}{2010} & \multicolumn{2}{|l|}{2013} & \multicolumn{2}{|l|}{2015} \\
\hline & & ha & $\%$ & ha & $\%$ & ha & $\%$ \\
\hline 1 & Bush & 715.89 & 0.30 & 601.20 & 0.25 & 438.31 & 0.18 \\
\hline 2 & Public Facility & 283.90 & 0.12 & 316.11 & 0.13 & 302.62 & 0.12 \\
\hline 3 & Industry & 9.83 & 0.00 & 9.69 & 0.00 & 12.79 & 0.01 \\
\hline 4 & Commercial & 160.16 & 0.07 & 267.62 & 0.11 & 431.1 & 0.17 \\
\hline 5 & Residential & 1111.49 & 0.46 & 1049.34 & 0.43 & 919.72 & 0.37 \\
\hline 6 & Open space & 136.49 & 0.06 & 173.80 & 0.07 & 313.23 & 0.13 \\
\hline 7 & Rivers & 55.25 & 0.02 & 53.59 & 0.02 & 53.08 & 0.02 \\
\hline
\end{tabular}

In this study, land use change interaction took place within a neighborhood that is determined through model calibration using a circular neighborhood within 500-meter radius from the LRT line. The size area of each land use will be used as one of the variables in the analysis. It consists of the bush, public facilities, industrial areas, residential, open spaces, and rivers. Another variable that is also used in the analysis is the distance from land use to the LRT line. 


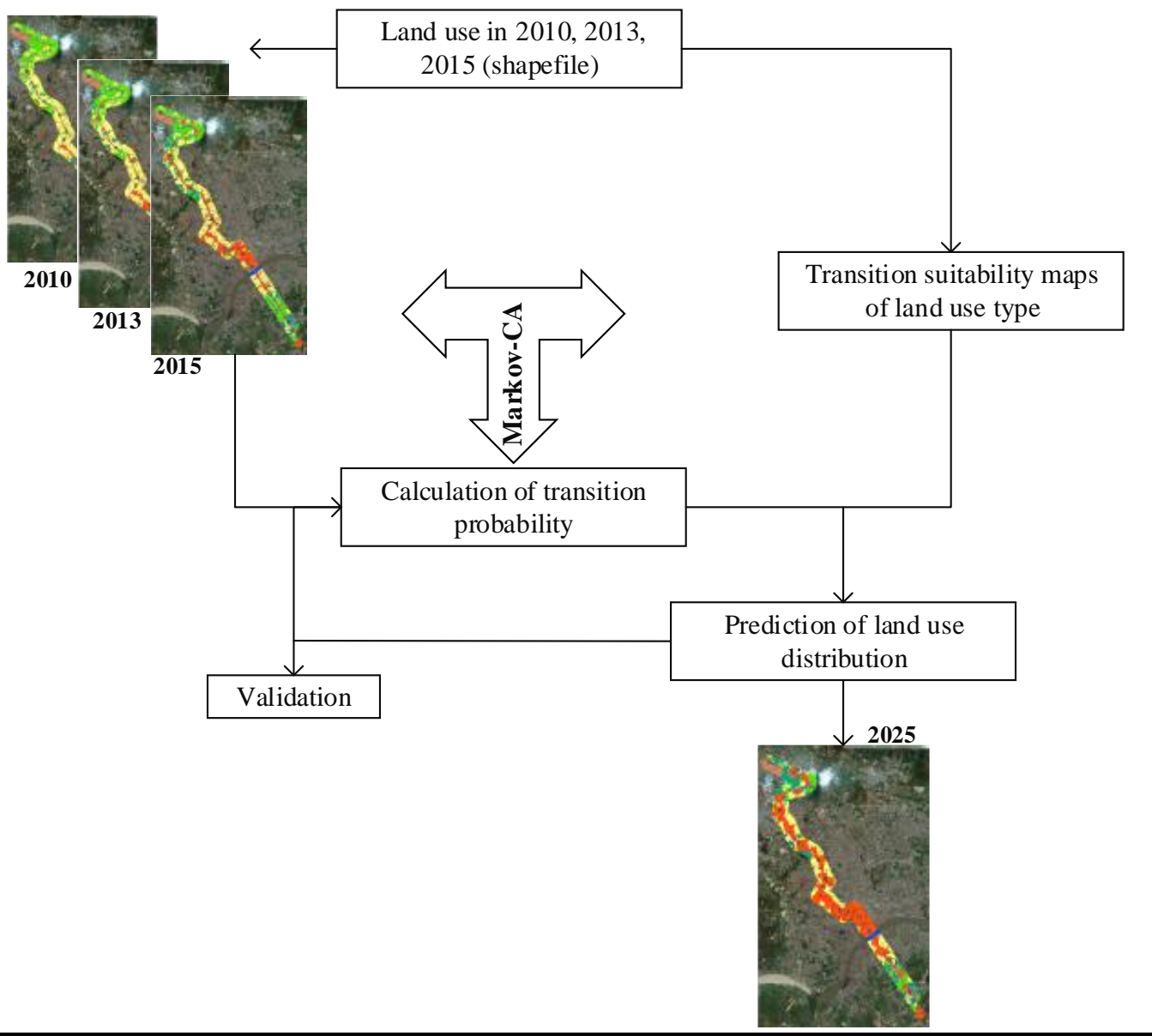

Figure 1. Flowchart of The Methodology

The Markov-Cellular Automata model required a validation process. The data for this validation process used a combination of maps in 2010 and 2013; in other words, the projected map is 2015. The validation results showed that the Kappa value is 0.8401 , which means that the value showed a good quality model. This Kappa value confirmed that good predictions were made by the model regarding the probability of each land use change (Oliveira, K.B, et al 2018)

The probability of land use changes coming from input has been used. This process will produce output in the transition area and transition probabilities matrix which is in the form of a land-use change opportunity matrix. The following is land-use change opportunity matrix with the code (1) Bush, (2) Public Facility, (3) Industry, (4) Commercial, (5) Residential, (6) Open space, and (7) Rivers.

Table 2. The matrix of Transition land use change in LRT Palembang (\%), based in 2015-2025

\begin{tabular}{llllllll}
\hline & 1 & 2 & 3 & 4 & 5 & 6 & 7 \\
\hline 1 & 0.2910 & 0.0196 & 0.0027 & 0.1777 & 0.1222 & 0.3839 & 0.0030 \\
2 & 0.0031 & 0.7015 & 0.0024 & 0.1471 & 0.1153 & 0.0251 & 0.0054 \\
3 & 0.2579 & 0.0031 & 0.5759 & 0.0686 & 0.0427 & 0.0514 & 0.0003 \\
4 & 0.0096 & 0.0977 & 0.0505 & 0.6979 & 0.1364 & 0.0056 & 0.0023 \\
5 & 0.0453 & 0.0479 & 0.0042 & 0.3830 & 0.4816 & 0.0322 & 0.0057 \\
6 & 0.0018 & 0.0167 & 0.0059 & 0.5409 & 0.0283 & 0.4032 & 0.0032 \\
7 & 0.0004 & 0.0597 & 0.0010 & 0.1107 & 0.0250 & 0.0208 & 0.7824 \\
\hline
\end{tabular}


The matrix (Table 2) shows there has been changing of land use patterns in the Palembang LRT corridor. The highest land use change is from public facilities to industry by $57 \%$, then land use change from open space to commercial by $54 \%, 5$ out of 6 land uses change to commercial use are above $10 \%$. This pattern of changes shows that LRT development in Palembang made the land use pattern in the LRT corridor turned into land use that has higher economic value, namely industry and commercial.

Table 3. Land Use Change in Corridor LRT Palembang 2015-2025

\begin{tabular}{llrrr}
\hline \multirow{2}{*}{ No } & \multirow{2}{*}{ Land use } & \multicolumn{2}{c}{ Land use (ha) } & Change (\%) \\
\cline { 3 - 4 } & & 2015 & 2025 & -0.594 \\
1 & Bush & 438.31 & 178.17 & 0.043 \\
2 & Public Facility & 302.62 & 315.49 & 1.878 \\
3 & Industry & 12.79 & 36.81 & 1.208 \\
4 & Commercial & 431.1 & 951.70 & -0.347 \\
5 & Residential & 919.72 & 600.93 & 0.073 \\
6 & Open space & 313.23 & 335.95 & -0.026 \\
7 & Rivers & 53.08 & 51.72 & \\
\hline
\end{tabular}

Land use change from 2015 to 2025 on the LRT corridor shows that the changes are dominated by commercial and industrial land use. On the transition map below (see Figure 2 ), it can be seen where the location of land use changes that turned into commercial area. The predicted increase in commercial land use in 2025 by $120 \%$. Modeling results show that commercial land use has a progressive increase until 2025; this commercial land use will dominate until $38 \%$ of land use in the LRT corridor.

Table 4. Land Use Changes in Corridor LRT Palembang Based On Each Land Use

\begin{tabular}{|c|c|c|c|}
\hline Land use (2015) & Land use change & Transition rate $(\%)$ & Size of change 2025 (ha) \\
\hline Bush & Bush & 0.291 & 127.55 \\
\hline \multirow[t]{6}{*}{438.31 ha } & Public Facility & 0.0196 & 8.59 \\
\hline & Industry & 0.0027 & 1.18 \\
\hline & Commercial & 0.1777 & 77.89 \\
\hline & Residential & 0.1222 & 53.56 \\
\hline & Open space & 0.3839 & 168.27 \\
\hline & Rivers & 0.003 & 1.31 \\
\hline Public Facility & Bush & 0.0031 & 0.94 \\
\hline \multirow[t]{6}{*}{302.62 ha } & Public Facility & 0.7015 & 212.29 \\
\hline & Industry & 0.0024 & 0.73 \\
\hline & Commercial & 0.1471 & 44.52 \\
\hline & Residential & 0.1153 & 34.89 \\
\hline & Open space & 0.0251 & 7.60 \\
\hline & Rivers & 0.0054 & 1.63 \\
\hline Industry & Bush & 0.2579 & 3.30 \\
\hline \multirow[t]{6}{*}{12.79 ha } & Public Facility & 0.0031 & 0.04 \\
\hline & Industry & 0.5759 & 7.37 \\
\hline & Commercial & 0.0686 & 0.88 \\
\hline & Residential & 0.0427 & 0.55 \\
\hline & Open space & 0.0514 & 0.66 \\
\hline & Rivers & 0.0003 & 0.00 \\
\hline Commercial & Bush & 0.0096 & 4.14 \\
\hline \multirow{6}{*}{431.1 ha } & Public Facility & 0.0977 & 42.12 \\
\hline & Industry & 0.0505 & 21.77 \\
\hline & Commercial & 0.6979 & 300.86 \\
\hline & Residential & 0.1364 & 58.80 \\
\hline & Open space & 0.0056 & 2.41 \\
\hline & Rivers & 0.0023 & 0.99 \\
\hline Settlement & Bush & 0.0453 & 41.66 \\
\hline \multirow[t]{4}{*}{919.72 ha } & Public Facility & 0.0479 & 44.05 \\
\hline & Industry & 0.0042 & 3.86 \\
\hline & Commercial & 0.383 & 352.25 \\
\hline & Residential & 0.4816 & 442.94 \\
\hline
\end{tabular}




\begin{tabular}{llll}
\hline Land use (2015) & Land use change & Transition rate (\%) & Size of change 2025 (ha) \\
\hline & Open space & 0.0322 & 29.61 \\
Open space & Rivers & 0.0057 & 5.24 \\
313.23 ha & Bush & 0.0018 & 0.56 \\
& Public Facility & 0.0167 & 5.23 \\
& Industry & 0.0059 & 1.85 \\
& Commercial & 0.5409 & 169.43 \\
& Residential & 0.0283 & 8.86 \\
Rivers & Open space & 0.4032 & 126.29 \\
53.08 ha & Rivers & 0.0032 & 1.00 \\
& Bush & 0.0004 & 0.02 \\
& Public Facility & 0.0597 & 3.17 \\
& Industry & 0.001 & 0.05 \\
& Commercial & 0.1107 & 5.88 \\
& Residential & 0.025 & 1.33 \\
& Open space & 0.0208 & 1.10 \\
& Rivers & 0.7824 & 41.53 \\
\hline
\end{tabular}

The prediction result showed that the most significant land use change is from residential land use into commercial use, which is 352.25 ha (38.3\%). This result shows that residential is the easiest land use to change into commercial uses.

When viewed from the figure, the commercial land increases the most compared to other land uses, which is equal to 520.6 ha, where it can be seen from Figure 2 and Table 4. The additional area comes from the residential land use of 352.25 ha, bushes of 77.89 ha, public facilities of $44.52 \mathrm{ha}$, industry of $0.88 \mathrm{ha}$, open space of $169.43 \mathrm{ha}$, and river of 5.88 ha.

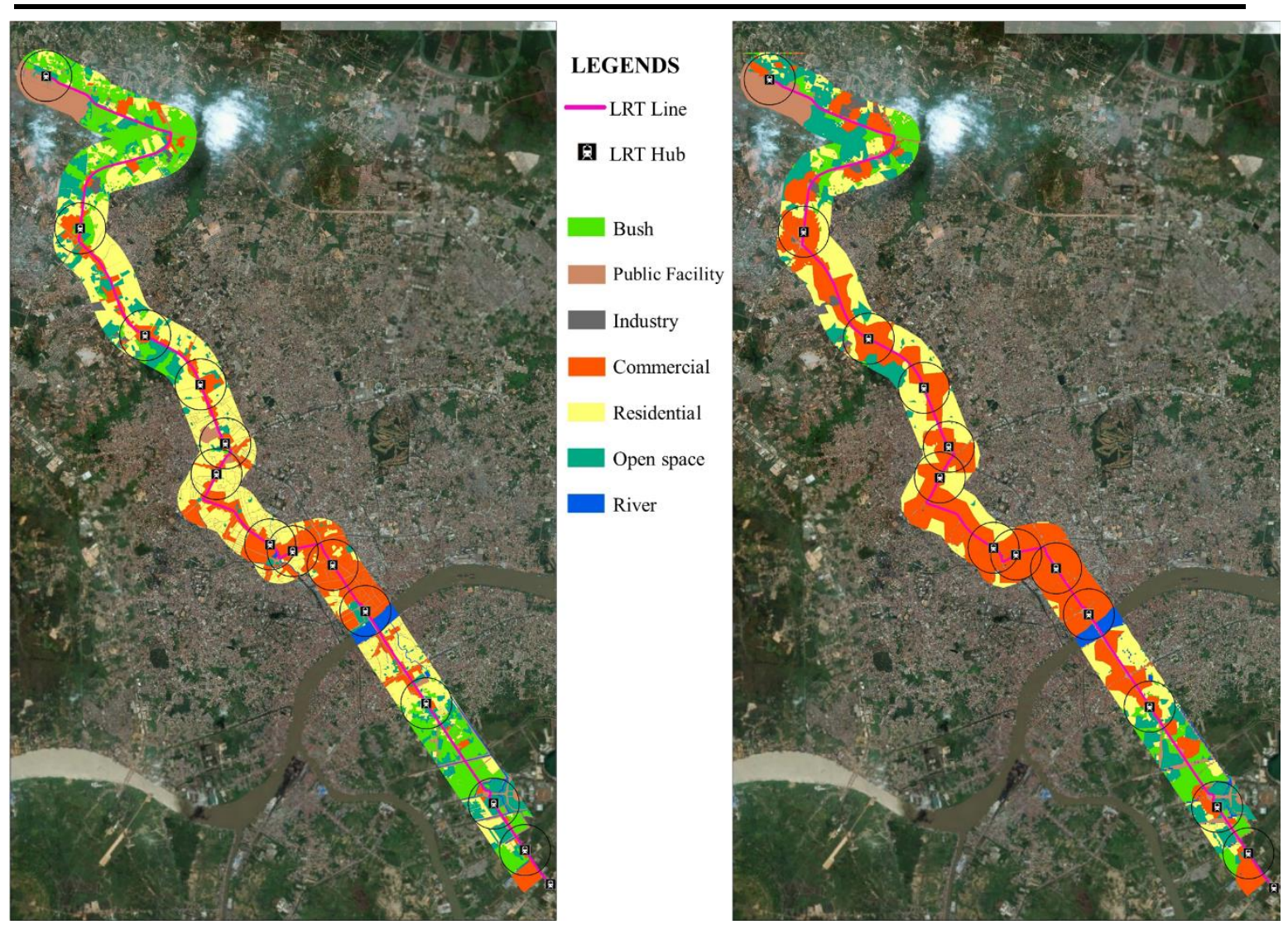

Figure 2. Land Use Change in Corridor LRT Palembang 2015-2025 


\section{CONCLUSIONS}

In general, the results of predictions of land use changes in the LRT corridor indicated that there has been a change in each existing land use. This model result shows that the development of the LRT in Palembang will lead to the dynamics of activities reflected in land use. The commercial land use that tends to increase sharply shows that the LRT, which is one of the public transportations in Palembang has triggered the growth of activities that have high economic value. This land use change pattern can be an input for policies in developing the area around the LRT such as the development of Transit-Oriented Development (TOD).

\section{REFERENCES}

Chapin, S. F, and Kaiser, E. J. (1979). Urban Land Use Planning. Urbana and Chicago: University of Illinois Press. Coyle, J. J., Bardi, E. J., and Novack, R. A. (2000). Transportation. USA: South-Western College Publishing.

Dittmar, H, and Ohland, G. (2012). The New Transit Town: Best Practices in Transit-Oriented Development. Washington DC: Island Press.

Goldberg, M, and Chinloy, P. (1994). Urban Land Economics. Canada: John Wiley \& Sons Inc.

Gray, G. E, and Hoel, L. A. (1992). Public Transportation: Planning, Operations, and Management. USA: Prentice Hall.

Kenworthy, J. (2008). "An International Review of The Significance of Rail in Developing More Sustainable Urban Transport Systems in Higher Income Cities." World Transport Policy \& Practice, Vol. 14, No. 2.

Koomen, E, et al. (2007). "Modelling Land Use-Change." The Geojurnal Library. US: Springer, Vol 90.

Oliveira, K.B, et all. (2018). "Markov chains and cellular automata to predict environments subject to Desertification". Journal of Environmental Management 225 (2018) 160-167

Tamin, O. Z. (2000). Perencanaan dan Pemodelan Transportasi. Bandung: Penerbit ITB.

Waseem, M. et all. (2015). "Land use/land cover change detection and prediction in the north-western coastal desert of Egypt using Markov-CA". Applied Geography 63 (2015) 101-112

Wright, L and Fjellstrom, K. (2002). Opsi Angkutan Massal. Eschborn: Deutsche Gesellschaft für Technische Zusammenarbeit (GTZ). 